\title{
Manufacture of sapphire ribbons with low dislocation density
}

\author{
R.I.Safronov, L.A.Litvinov, A.V.Voloshin, V.F.Bochkov \\ Institute for Single Crystals, STC "Institute for Single Crystals", \\ National Academy of Sciences of Ukraine, \\ 60 Nauky Ave., 61001 Kharkiv, Ukraine
}

Received August 20, 2015

\begin{abstract}
Uniform thermal field with the axial temperature gradient of $11.6 \mathrm{~K} / \mathrm{cm}$ was formed in a cylindrical heater. There were obtained $15 \times 85 \times 300 \mathrm{~mm}^{3}$ sapphire ribbons with dislocation density up to $10^{3} \mathrm{~cm}^{-2}$. The dislocation density of sapphire ribbons at the axial temperature gradient of $11.6 \mathrm{~K} / \mathrm{cm}$ was found to be comparable with the one in the crystals obtained by the Czochralski and Kyropoulos methods.
\end{abstract}

Keywords: sapphire, EFG, Stepanov method, dislocation.

В цилиндрическом нагревателе сформировано равномерное тепловое поле с осевым градиентом температуры $11,6 \mathrm{~K} / \mathrm{cm}$. Получены сапфировые ленты размером $15 \times 85 \times 300 \mathrm{mм}^{3}$ с плотностью дислокаций до $10^{3} \mathrm{~cm}^{-2}$. Установлено, что при осевом градиенте температуры $11,6 \mathrm{~K} / \mathrm{cm}$ плотность дислокаций сапфировых лент сопоставима с плотностью дислокаций в кристаллах, получаемых методами Киропулоса и Чохральского.

Отримання малодислокаційних сапфірових стрічок. Р.І.Сафронов, Л.А.Литвинов, О.В.Волошин, В.Ф.Бочков.

у циліндричному нагрівачі сформовано рівномірне теплове поле $з$ осьовим градієнтом температури $11,6 \mathrm{~K} /$ см. Отримано сапфірові стрічки розміром $15 \times 85 \times 300 \mathrm{~mm}^{3}$ із щільністю дислокацій до $10^{3} \mathrm{~cm}^{-2}$. Встановлено, що при осьовому градієнті температури $11,6 \mathrm{~K} / \mathrm{cm}$ щільність дислокацій сапфірових стрічок зіставна із щільністю дислокацій у кристалах, що отримують методами Кіропулоса і Чохральського.

\section{Introduction}

As experimentally shown, the strength of sapphire considerably exceeds that of the standard materials used for protection of objects against extremely high impact loads $[1,2]$. The mentioned characteristic is connected with the sapphire structure perfection. As a rule, protective products are obtained from sapphire by the Stepanov method (EFG) which is the most efficient, but not providing the high structure perfection of manufactured articles.

While studying the temperature field and calculating the thermoelastic stresses the authors of [3] assumed that in sapphire ribbons with thickness of $\sim 5 \mathrm{~mm}$ and more the value of maximal tangential stresses becomes sufficient for activation of the basic slip system which promotes the stress relief in the growing crystal. In relatively thick ribbons the dislocations which belong to the rigid prismatic system are not generated, and characteristic block structure is not formed. Nevertheless, the problem of crystals obtaining in the form of ribbons with the large thickness and width has not been solved so far.

Sapphire is obtained by different methods which may be divided into two groups. The first of them includes the Verneuil and Stepanov methods in which crystal grows 

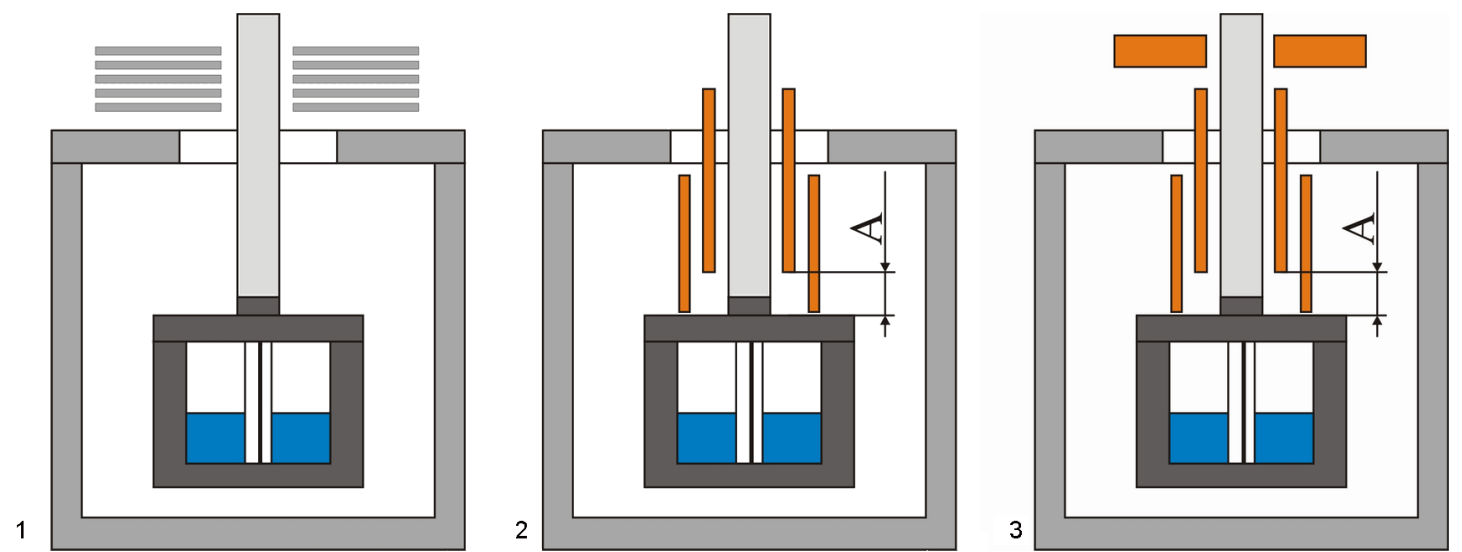

Fig. 1. Scheme of thermal zone of the growth setup: 1 - initial shielding; 2 - vertical shields; 3 - combination of vertical and horizontal shields.

from the melt film. These technologies are distinguished by the high growth rates, high temperature gradients in the growth zone and, consequently, high dislocation concentration. The Czochrakski, Kyropoulos and HDS methods belonging to the second group make it possible to obtain the crystals with the low dislocation density, but at the low growth rate.

The aim of the present work is to combine advantages of the both groups of the methods in order to use the Stepanov method for obtaining the sapphire ribbons with dislocation density comparable with the one in the crystals grown by the Kyropoulos and HDS methods at the high growth rates.

\section{Experimental}

Sapphire ribbons with (11-20) plane on the wide side and direction $\langle 10-10\rangle$ along the growth axis, $85 \mathrm{~mm}$ of wide, $15 \mathrm{~mm}$ of thick and $300 \mathrm{~mm}$ of long were grown by the EFG method [4] by means of a setup of "SPECTR" type under redundant $(0.12-0.15$ bar $)$ pressure of argon in a chamber. There was used the "standard" thermal zone (Fig. 1) with carbon graphite shields and graphite heater, which is compatible with the crucible diameter equal to $120 \mathrm{~mm}$. There was chosen the hybrid design of the crucible $[5,6]$ with capillary system mounted into the crucible and a shaper manufactured as a removable facility.

Temperature gradient was measured by moving of tungsten-rhenium thermocouple. The temperature gradient $\left(\Delta T_{z}\right)$ along the crucible height did not exceed $2 \mathrm{deg} / \mathrm{cm}$ to provide the minimal overheating of the melt. However, the rate of heat removal above the shaper was high enough $\left(\Delta T_{r}=40\right.$,

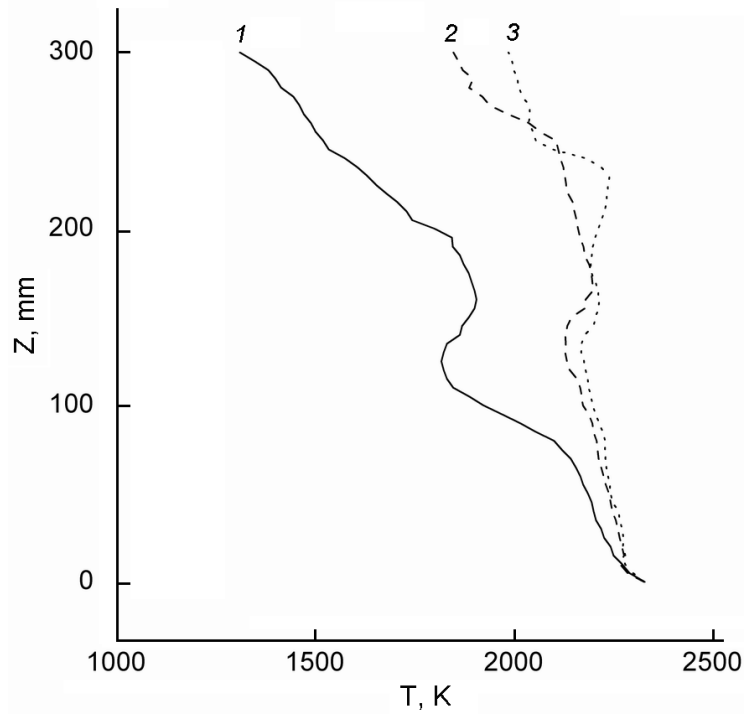

Fig. 2. Temperature distributions within the thermal zone along the pulling axis. 1 - initial shielding $\Delta T_{z} \sim 36 \mathrm{~K} / \mathrm{cm} ; 2-$ vertical shields, $\Delta T_{z} \sim 16 \mathrm{~K} / \mathrm{cm} ; 3-$ combination of vertical and horizontal shields, $\Delta T_{z} \sim 11.6 \mathrm{~K} / \mathrm{cm}$.

$\Delta T_{z}=50 \mathrm{~K} / \mathrm{cm}$ ), and this could favour occurrence of the essential thermoelastic stresses in the growing crystal. The system of flat and cylindrical molybdenum shields placed around the shaper made it possible to diminish $\Delta T_{r}$ and $\Delta T_{z}$ in the growth zone and essentially reduce the temperature difference in the zone of plastic deformation (down to $\Delta T_{r}=10, \Delta T_{z}=12 \mathrm{~K} / \mathrm{cm}$ ).

Crystal structure perfection is usually related to the crystal growth conditions [7, 8]. The dislocations were revealed by the method of chemical etching. The surfaces (0001) of the ribbons which were not subjected to additional grinding and polishing 


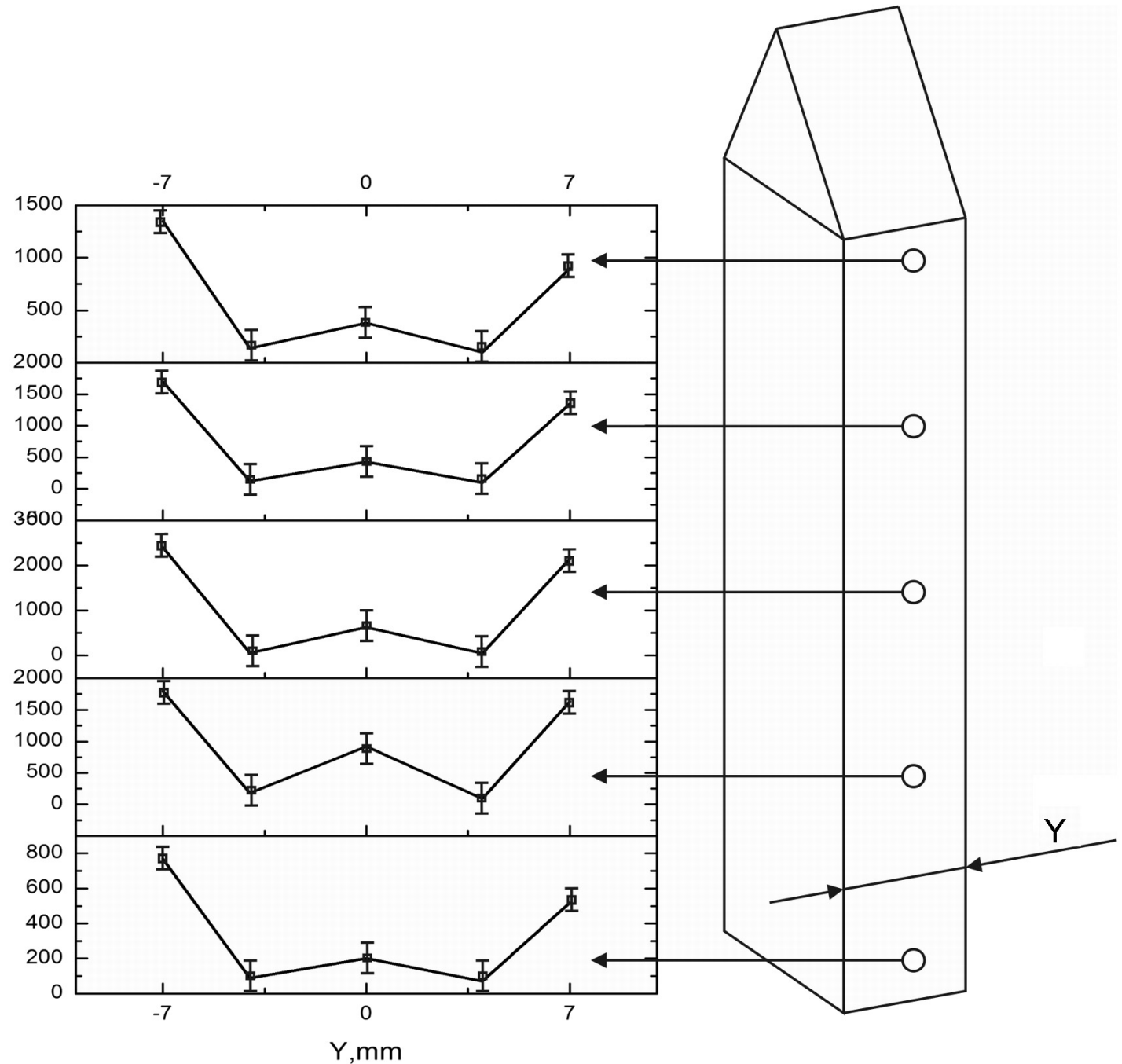

Fig. 3. Distribution of dislocations over cross-section of $15 \times 85 \mathrm{~mm}^{2}$ ribbon perpendicular to the growth axis.

were etched during $2 \mathrm{~h}$ in an annealing furnace in vacuum at $1925^{\circ} \mathrm{C}$. The revealed etch patterns were calculated on the sections with area of $\sim 1 \mathrm{~mm}^{2}$ along the ribbon thickness at different distances from the seed. The dislocation distribution $(\rho)$ was estimated with respect to the basic surface of the ribbon.

\section{Results and discussion}

As it is known, in coaxial growth process the crystal located inside the coaxial grows under more comfort thermal conditions (at the temperature gradient lower than the exterior one) [4]. For the crystals of different shape the components of the stress tensor may be expressed in certain approximation using the second derivatives of the temperature with respect to $z$. The crystal growth at the low $\Delta T_{z}$ promotes the structure perfec- tion, but impedes the process of seeding and maintenance of the crystal shape stability.

Based on the mentioned above we worked out a shielding which imitates the coaxial growth (Fig. 1). Thereat, the external shield is meant for compensation of non-uniform thermal field of the cylindrical heater, whereas the internal shield forms the axial temperature gradient and sets a rectangular shape of the thermal field. The clearance A (Fig. 1) creates the elevated temperature gradient above the shaper in a narrow zone of the crystal plasticity, that is necessary for facilitation of the process of seeding and maintenance of stability of the crystal shape during the growth.

As seen from the graph presented in Fig. 2, the vertical shields diminish the axial $\Delta T_{z}$ to $16 \mathrm{~K} / \mathrm{cm}$. The additional horizontal shields reduce $\Delta T_{z}$ to $11.6 \mathrm{~K} / \mathrm{cm}$. 
Calculation of dislocations on the basic crystal face shows that at $\Delta T_{z} \sim 36 \mathrm{~K} / \mathrm{cm}$ (Fig. 3) $\rho \leq 10^{4} \mathrm{~cm}^{-2}$ for thermal zone with $\Delta T_{z} \sim 11.6 \mathrm{~K} / \mathrm{cm}$ the dislocation density is $10^{3} \mathrm{~cm}^{-2}$.

In the direction $\langle 11-20\rangle$ (Fig. 3) the dislocations are distributed non-uniformly. At scanning the plate from the center to the edge there is observed the major decrease of the dislocation density from 600-900 to $250 \mathrm{~cm}^{-2}$. In the narrow region neighbouring to the wide side of the plate the dislocation density rises sharply to $4000 \mathrm{~cm}^{-2}$. This is bound up with the defect layer and local stresses related to it. Thereat, the width of the layer with elevated dislocation concentration coincides with the width of the surface-adjacent layer and it does not exceed $0.6 \mathrm{~mm}$. In the surface-adjacent layer zone the dislocation density is lower than the critical one that is insufficient for the formation of micro-blocks.

$\mathrm{X}$-ray diffractometric analysis confirmed absence of the micro-blocks along the length for the plates grown in the thermal zone with $\Delta T_{z}=11.6 \mathrm{~K} / \mathrm{cm}$, as well as for the plates obtained in the zone with $\Delta T_{z}=16 \mathrm{~K} / \mathrm{cm}$ at a pulling rate up to $30 \mathrm{~mm} / \mathrm{h}$. The rise of the pulling rate up to $40 \mathrm{~mm} /$ hour led to the growth of the dislocation concentration to $10^{3} \mathrm{~cm}^{-2}$ in the central part at $\Delta T_{z}=$ $11.6 \mathrm{~K} / \mathrm{cm}$ without formation of the microblocks, and to $4 \cdot 10^{4} \mathrm{~cm}^{-2}$ at $\Delta T=16 \mathrm{~K} / \mathrm{cm}$. In the case of the shielding with $\Delta T_{z}=$ $16 \mathrm{~K} / \mathrm{cm}$ we observed formation of the micro-blocks with disorientation angles from $2^{\prime \prime}$ to $10^{\prime \prime}$ in the central part, while in the vicinity of the surface $(11-20)$ the dislocation density remained practically unchanged. This fact confirms the assumption about connection of the elevated dislocation concentration at the growth surface (11-20) with the surface-adjacent defect layer.

\section{Conclusions}

Influence of constructional and thermal parameters on the formation of dislocation structures in sapphire ribbons with the large thickness and width was studied. In a cylindrical heater there was formed the uniform rectangular thermal field with the axial temperature gradient of $11.6 \mathrm{~K} / \mathrm{cm}$. There was solved the problem of seeding and maintenance of the stability of the growing crystal shape at the low temperature gradient, by creating the elevated temperature gradient in a narrow plasticity zone above the shaper. In the thermal zone with the axial temperature gradient of $11.6 \mathrm{~K} / \mathrm{cm}$ there were obtained the sapphire ribbons with dimension $15 \times 85 \times 300 \mathrm{~mm}^{3}$ and dislocation density up to $10^{3} \mathrm{~cm}^{-2}$ in the marketable part of the crystal $(\sim 90 \%)$. The dislocation density of the sapphire ribbons at the axial temperature gradient of $11.6 \mathrm{~K} / \mathrm{cm}$ was found to be comparable with the one in the crystals obtained by the Czochralski and Kyropoulos methods.

\section{References}

1. A.B.Sinani, A.S.Vlasov, E.L.Zilberbrand et al., Math.AN.Ser.Nat., 68, 810 (2004).

2. P.V.Konevsky, PhD. Tehn. Sciences, Kharkov (2004).

3. L.L.Kuandikov, S.I.Bakholdin, I.L.Shulpina, P.I.Antonov, Math.AN.Ser.Nat., $\quad 68,784$ (2004).

4. A.V.Stepanov, Math.USSR Acad. Sci.Ser.Nat., 33, 1946 (1969).

5. E.R.Dobrovinsky, L.A.Litvinov, V.V.Pishchik, Encyclopedia Sapphire, Kharkov Institute for Single Crystals (2004) [in Russian].

6. Patent of Ukraine No.89883 (2010).

7. H.S.Bagdasarov, E.R.Dobrovinsky, V.V.Pishchik et al., Crystallography, 18, 390 (1973).

8. V.L.Indenbom, Math.USSR Acad. Sci.Ser. Nat., 37, 2258 (1973).

9. Author's Certificate No.1009117 (1982). 